\begin{tabular}{ccr} 
FOLIA & $\begin{array}{c}\text { ENTOMOLOGICA } \\
\text { ROVARTANI HÖZLEMÉNYEK A R ICA }\end{array}$ \\
Volume 81 & 2020 & pp. $123-128$ \\
\hline
\end{tabular}

\title{
Dyscia innocentaria (Christoph, 1885) in the Pannonian Region (Lepidoptera: Geometridae: Ennominae)
}

\author{
Balázs Tót H \\ Hungarian Natural History Museum, Department of Zoology, H-1088, Budapest, Baross utca 13, \\ Hungary.E-mail:toth.balazs@nhmus.hu
}

\begin{abstract}
Dyscia innocentaria (Christoph, 1885) is reported from the Pannonian Region for the first time: altogether 16 specimens were found in the Hungarian Natural History Museum, collected in Deliblát (Deliblato Sands, Serbia) in 1895 and the 1910s by Hungarian lepidopterists. These are the oldest known $D$. innocentaria specimens from Serbia. With 7 figures.
\end{abstract}

Key words - Deliblato Sands, Dyscia conspersaria, genitalia, new records, Antal Schmidt, Serbia

\section{INTRODUCTION}

The genus Dyscia Hübner, 1825 (type species: Geometra conspersaria [Denis et Schiffermüller], 1775) is represented by eleven species in Europe (MÜLLER et al. 2019). They are difficult to distinguish by external features; identification often requires dissection of genitalia. Four Dyscia species are known to occur in or around the Pannonian Region: D. raunaria (Freyer, 1851) (along the Adriatic coasts, eastwards roughly to Celje, Slovenia), D. innocentaria (Christoph, 1885) (along the Adriatic coasts), D. conspersaria (in the area roughly surrounded by Linz in Austria; Brno in Czech Republic; Košice in Slovakia and Pécs in Hungary; with an isolated population in the Trascău Mountains, Romania), and D. fagaria (Thunberg, 1794) (eastern Austria to Wien; Ukrainian Carpathians) (SKoU \& SiHvonen 2015).

Dyscia innocentaria is distributed from the eastern half of the Mediterranean region to China, through the Caucasus, Levant and Central Asia; with isolated occurrence in central Ukraine. It can be found in xerothermic habitats (SKOU \& Sinvonen 2015). Perhaps $D$. innocentaria is most similar to $D$. conspersaria but they can usually be distinguished by the shape of the discal spot in the forewing: in $D$. innocentaria it is monochromatic and narrow, while that of $D$. conspersaria usually has a light central area and the spot itself is often broader than in the former species. In the male genitalia the large ventral process of valva, as well 
as the shape of sterigma in the female genitalia, are diagnostic characters for $D$. innocentaria (see Skou \& SiHvoneN (2015) for comparison).

This paper presents the first records of $D$. innocentaria in the Pannonian Region, based on specimens deposited in the Hungarian Natural History Museum (HNHM, Budapest).

\section{MATERIAL AND METHODS}

The main collection of HNHM from the Carpathian Basin was checked. Altogether $17 \mathrm{D}$. innocentaria specimens were found, mixed up with the material of $D$. conspersaria. Data of these specimens are as follows ("/" marks the end of a line; "//" indicates next label).

20: "Grebenác // 1911.V.2. / Ujhelyi S." (Fig. 1) (slide No. TB2015m: Fig. 5);

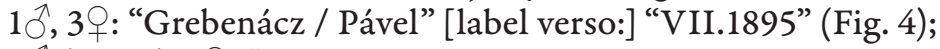

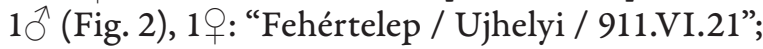

1 : data as previous but VI.19.,

$1 \hat{O}^{\dagger}$ : data as previous but VI.16.;

$1 \widehat{\gamma}, 1 \bigcirc$ : data as previous but 1911.V.;

1: "Fehértelep / 1914.VI.8." [without the name of the collector];

1ㅇ: "Deliblát / Schmidt // Fehér / telep / 914.VI.13" (Fig. 3) (slide No. TB2014f: Fig. 6);

1 : : data as previous but VI.10.;

19: "localitas / ac datum dubiosa" // "vide No. / 863-025, 1955" //

"Hungaria / Deliblat / Fehértelep / 1914 VI 8 / + 20485" [label verso:] "Dyscia conspersaria / turturaria Bsd.";

19: "localitas / ac datum dubiosa" // "vide No. / 863-025, 1955" // “Herkulesfürdő / 1930.VII.15 / へ 14179”.

Genitalia dissection was performed with the traditional method (GoZMÁnY 1965, Winter 2000). The genitalia were stained with eosine and mounted in Euparal, then photographed with an Olympus DP70 photographic microscope, using DPController and DPManager softwares. The pinned specimens were photographed with an Olympus Camedia C 7070 digital camera. Images were adjusted with Adobe Photoshop CS2. 

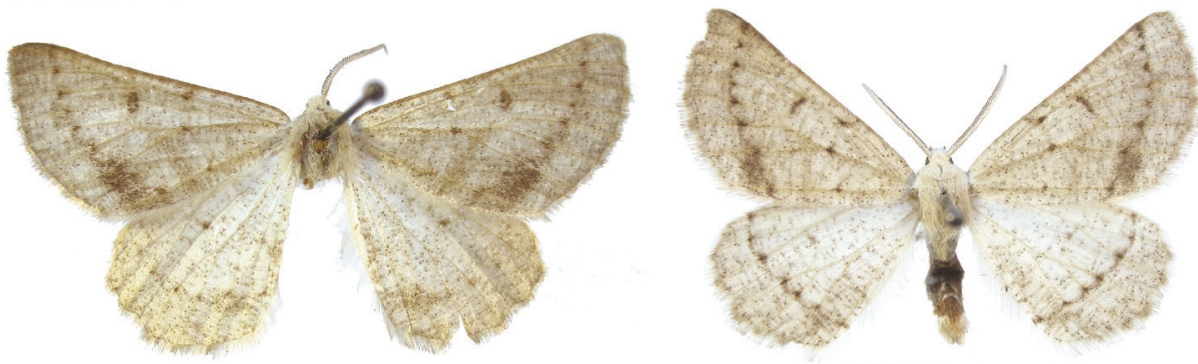

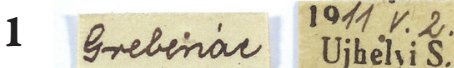
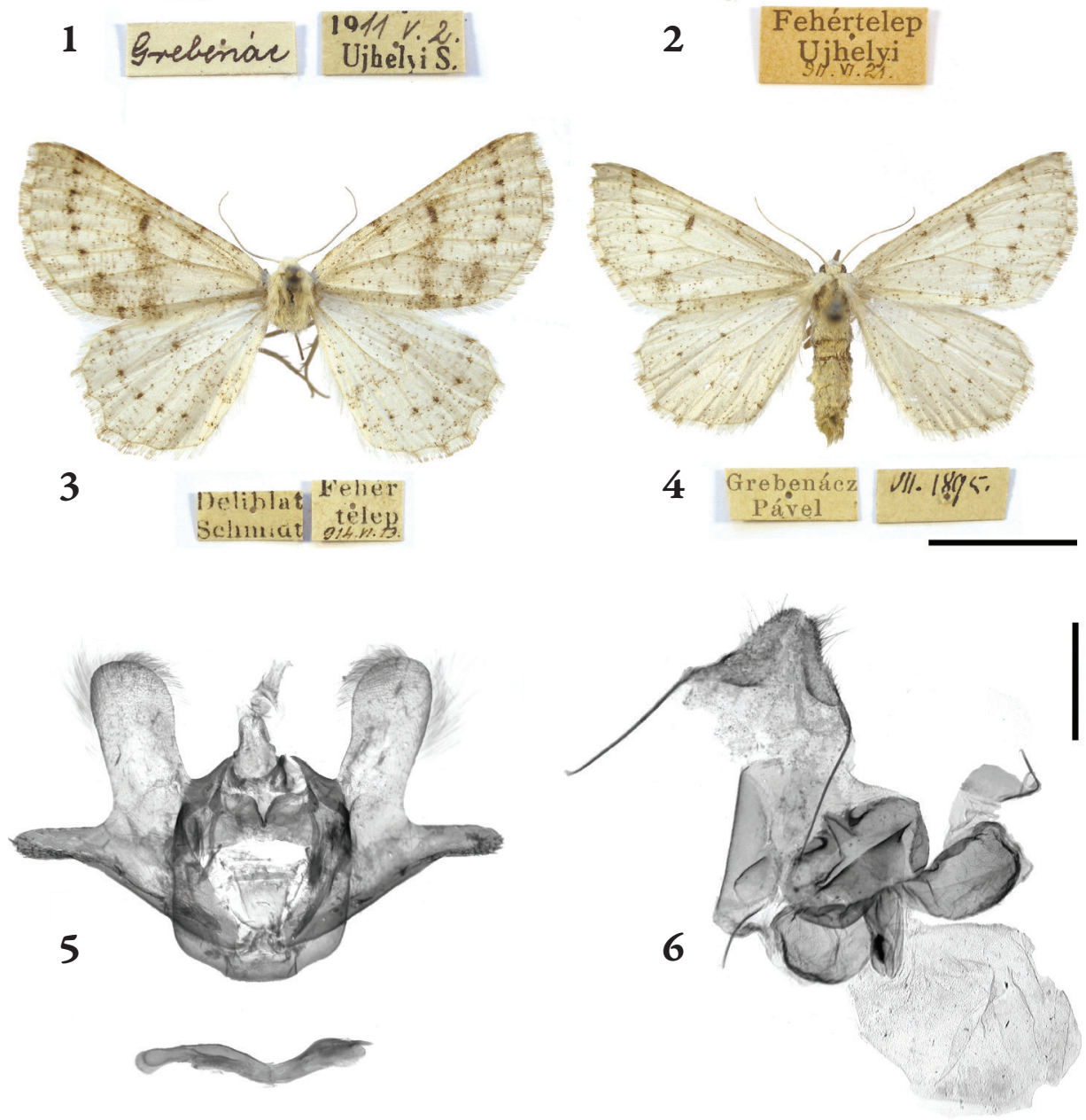

Figs 1-6. Dyscia innocentaria specimens from the Deliblato Sands and their labels: $1=$ male from Grebenac, Serbia (dissected), 2 = male from Šušara, Serbia, 3 = female from Šušara, Serbia (dissected), $4=$ female from Grebenac, Serbia, $5=$ male genitalia of the specimen depicted on Fig. 1 (slide No. TB2015m), 6 = female genitalia of the specimen depicted on Fig. 3 (slide No. TB2014f). Scale bar to Figs 1-4=10 mm; to Figs 5-6 = $1 \mathrm{~mm}$ (photos by Balázs Tóth) 


\section{RESULTS AND DISCUSSION}

Dyscia innocentaria was recently discovered in Serbia (Niš region) by BeSh Kov (2015). It was also found in Dobrogea, Romania (SzÉ KelY 2011).

The specimens presented in this paper were collected in "Grebenác" and "Fehértelep" from May to July. According to SKou \& SiHvonen (2015) they belong to the first generation of the species. Grebenác and Grebenácz both refer to Grebenac (Гребенац) village in Serbia, at the north-eastern edge of Deliblato Sands (a sand steppe area under nature protection) in the Banat Region. The settlement of Fehértelep, currently Šušara (Шушара), is also situated close to the Deliblato Sands, ca $10 \mathrm{~km}$ west-northwest from Grebenac. These localities are at the southern edge of the Great Hungarian Plain, thus belong to the Pannonian Region.

The last two listed specimens were re-labelled by Zsigmond Velez, a curator of HNHM just after World War II, and he destroyed their original labels (BÁLIN T 2016). Data on Velez's labels should be treated as doubtful, that is why "Herkulesfürdő" (currently Băile Herculane, Romania) is not regarded here as an authentic locality for D. innocentaria. On the contrary, the other re-labelled specimen has the same collecting site and date as one of the specimens with original labels, so it is possible that these data are reliable. This latter specimen was misidentified by Velez as Dyscia conspersaria turturaria (Boisduval, 1840); currently this name is regarded as valid for a subspecies of $D$. conspersaria in Provence, France (SKOU \& SiHvonen 2015).

The genitalia of the dissected male specimen (Fig. 5) show the large triangular ventral projection of valva, characteristic for $D$. innocentaria. The female genitalia (Fig. 6) have two lateral, rounded, sclerotised plates in the sterigma, also characteristic for this species. Therefore, identifications of the specimens presented were incorrect since collecting until now. These moths are the oldest $D$. innocentaria specimens currently known from Serbia, and the first ones representing the species in the Pannonian Region.

The distribution of D. conspersaria and D. innocentaria are depicted in Fig. 7. 


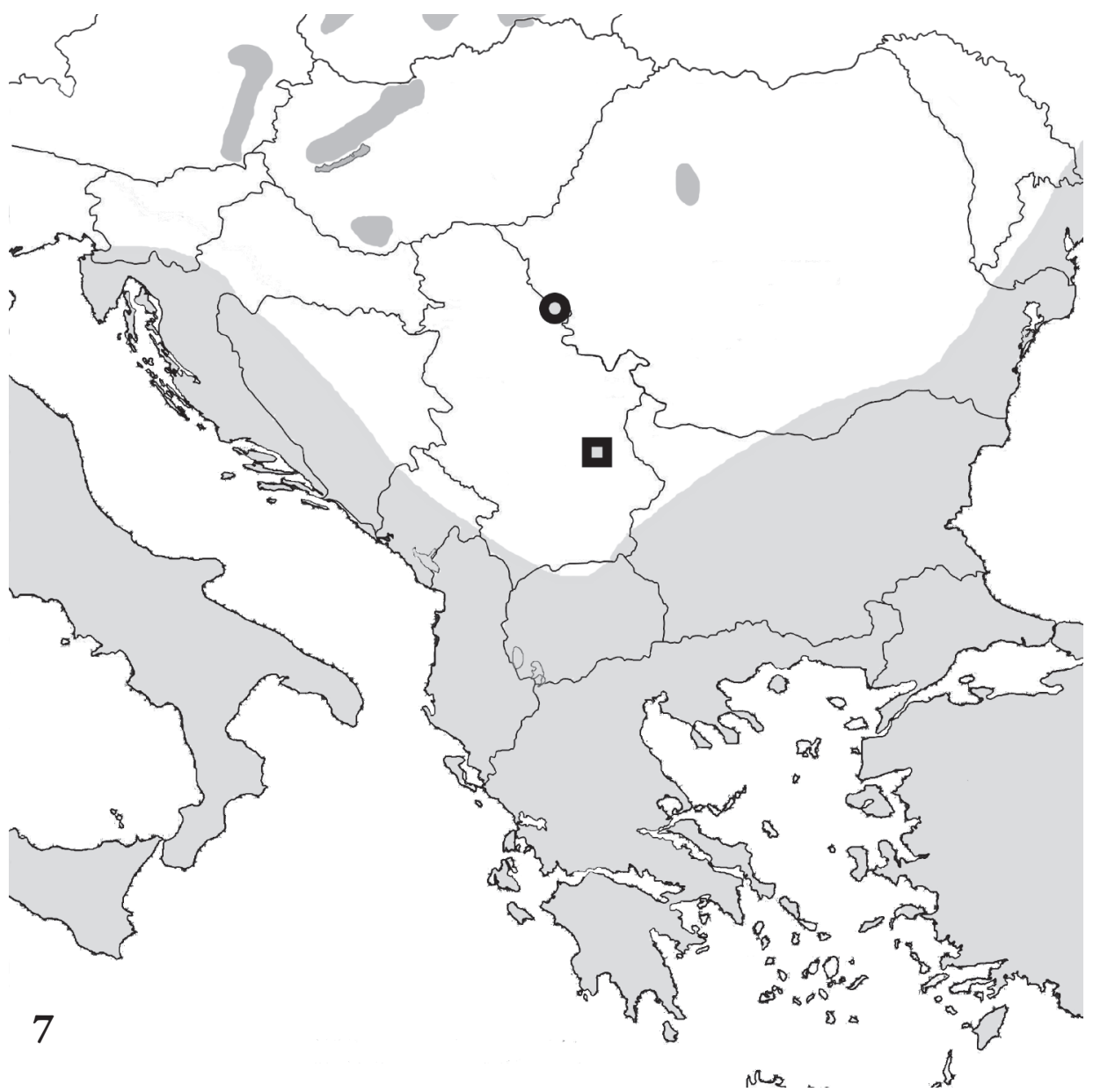

Fig. 7. Distribution of two Dyscia species in and around the Pannonian Region and in the Balkan Peninsula: dark grey patches $=D$. conspersaria [Denis et Schiffermüller], 1775; light grey field and shapes $=D$. innocentaria (Christoph, 1885) after SKOU \& SIHVONEN 2015); square $=$ record of Beshkov (2015) from Niš Region; circle = records of present paper from the Deliblato Sands

Acknowledgements - I am indebted to László Ronkay (HNHM) who checked and improved the manuscript. 


\section{REFERENCES}

BÁlint Zs. 2016: A magyar lepkészet egyik sötét oldala. [One of the dark sides of lepidopterology in Hungary.] - Magyar Természettudományi Múzeum blog. https://mttmuzeum.blog.hu/2016/04/18/a_magyar_lepkeszet_egyik_sotet_oldala [Accessed 21 October 2020.]

Besh kov S. 2015: Some new for Serbia and rare Lepidoptera species collected at light in eastern Serbia. - The Entomologist's Record and Journal of Variation 127: 127-134.

Gozmány L. 1965: Lepkék - Lepidoptera. - In: Magyarország Állatvilága (Fauna Hungariae), 16, 2. Akadémiai Kiadó, Budapest, 40 pp.

Müller B., Erlacher S., Hausmann A., Rajaei H., Sihvonen P. \& Skou P. 2019: Ennominae II. - In: Hausmann A., Sihvonen P., Rajaei H. \& Skou P. (eds): The geometrid moths of Europe 6. Brill, Leiden, $906 \mathrm{pp}$.

Skou P. \& Sihvonen P. 2015: Ennominae I. - In: HAusmann A. (ed.): The geometrid moths of Europe 5. Brill, Leiden, 657 pp.

Székely L. 2011: Moths of Romania 2: Geometridae - 1. Archiearinae, Ennominae, Alsophilinae, Orthostixinae, Geometrinae. - Disz-Tipo, Săcele, 196 pp.

Winter W. D. JR. 2000: Basic techniques for observing and studying moths \& butterflies. Memoirs of the Lepidopterists' Society No. 5. - Lepidopterists' Society, Los Angeles, xviii + $444 \mathrm{pp}$. 